\title{
Hubungan antara kadar asam urat dengan tekanan darah pada anak obes di Kecamatan Talawaan Kabupaten Minahasa Utara
}

\author{
${ }^{1}$ Herlin S. Sarundaitan \\ ${ }^{2}$ Sarah M. Warouw \\ ${ }^{2}$ Ari L. Runtunuwu
}

\author{
${ }^{1}$ Kandidat Skripsi Fakultas Kedokteran Universitas Sam Ratulangi Manado \\ ${ }^{2}$ Bagian Ilmu Kesehatan Anak Fakultas Kedokteran Universitas Sam Ratulangi Manado \\ Email: herlinselasarundaitan@yahoo.com
}

\begin{abstract}
Obesity is an increasing global health problem in many countries. The most common causes are genetic factor, lack of physical activity as well as combinations of these factors. Uric acid is an end product of purine metabolism. Elevated uric acid level is influenced by various factors such as alcohol, genetic, hypothyroidism, obesity, and highpurine diet. In children all over the world, the increased prevalence of overweight and obesity influences the prevalence of hypertension, especially primary hypertension. This study aimed to determine the relationship between the level of blood uric acid and blood pressure among obese children. This was an observational analytical study. Samples were obtained by using consecutive sampling method. This study was conducted at Talawaan North Minahasa during October 2015-January 2016. There were 38 obese children aged 13-15 years as samples, consisted of 14 males and 24 females. The results showed that the majority of samples were in the age categories 13 and 14 years; each category consisted of 17 samples (44.7\%). The lowest was age category of 15 years, consisted of 4 samples (10.5\%). The mean systolic blood pressure was $123.16 \mathrm{mmHg}(\mathrm{SD} \pm 12.967)$ and the mean diastolic blood pressure was 81.58 $\mathrm{mmHg}$ (SD \pm 11.514). The mean level of blood uric acid was $4.858 \mathrm{mg} / \mathrm{dL}$ (SD \pm .9328 ). The Pearson correlation statistical test for the relationship between uric acid level and systolic blood pressure showed a $\mathrm{P}$ value of $0.306(\mathrm{r}<0.02)$ and for the relationship between uric acid levels and diastolic blood pressure showed a P value of $0.152(r<0.02)$. Conclusion: There was a positive relationship between the level of blood uric acid and blood pressure among obese children but not statistically significant.
\end{abstract}

Keywords: uric acid, blood pressure, obesity

\begin{abstract}
Abstrak: Obesitas merupakan masalah kesehatan dunia yang semakin meningkat di berbagai negara. Penyebab yang paling sering menyebabkan obesitas ialah faktor genetik, kurangnya aktifitas fisik, serta kombinasi dari kedua faktor ini. Asam urat merupakan produk akhir metabolisme purin. Penyebab meningkatnya kadar asam urat dipengaruhi oleh berbagai macam faktor antara lain alkohol, genetik, hipotiroid, obesitas, dan diet tinggi purin. Pada populasi anak di seluruh dunia, peningkatan prevalensi kegemukan dan obesitas turut meningkatkan prevalensi hipertensi, terutama hipertensi primer. Penelitian ini bertujuan untuk mengetahui hubungan antara kadar asam urat dengan tekanan darah pada anak obes. Jenis penelitian ini analitik observasional dengan desain potong lintang. Sampel diperoleh dengan metode consecutive sampling. Penelitian ini dilakukan di Kecamatan Talawaan Kabupaten Minahasa Utara selama bulan Oktober 2015 - Januari 2016. Terdapat 38 anak obes berusia 13-15 tahun sebagai sampel, yang terdiri dari 14 anak laki-laki dan 24 anak perempuan. Hasil penelitian memperlihatkan bahwa sebagian besar responden berada pada kategori umur 13 dan 14 tahun masing-masing berjumlah 17 orang (44,7\%), dan terendah umur 15 tahun sebanyak 4
\end{abstract}


orang (10,5\%). Rerata tekanan darah sistol 123,16 mmHg (SD \pm 12,967) dan rerata tekanan darah diastol 81,58 mmHg (SD \pm 11,514). Rerata kadar asam urat responden 4,858 mg/dL (SD \pm 0,9328). Uji statistik Pearson Correlation untuk hubungan antara kadar asam urat dengan tekanan darah sistol menunjukkan nilai $\mathrm{P}=0,306(\mathrm{r}<0,02)$ dan untuk hubungan antara kadar asam urat dengan tekanan darah diastol menunjukkan nilai $\mathrm{P}=0,152(\mathrm{r}<0,02)$. Simpulan: Terdapat hubungan positif antara kadar asam urat darah dengan tekanan darah pada anak obes namun secara statistik tidak bermakna.

Kata kunci: asam urat, tekanan darah, obesitas

Obesitas didefinisikan sebagai akumulasi jaringan lemak di bawah kulit yang berlebihan dan terdapat di seluruh tubuh. Obesitas dapat terjadi pada semua golongan umur, akan tetapi pada anak biasanya timbul menjelang remaja dan dalam masa remaja. Obesitas merupakan masalah kesehatan dunia yang semakin sering ditemukan di berbagai negara. Prevalensi overweight dan obes meningkat pada anak di dunia dari 4,2\% di tahun 1990 menjadi 6,7\% di tahun 2010, dan diperkirakan akan mencapai 9,1\% di tahun 2020. ${ }^{1}$ Berdasarkan data Riset Kesehatan Dasar (Riskesdas) 2013 didapatkan prevalensi obesitas pada anak balita di tahun 2007, 2010, dan 2013 berdasarkan berat badan menurut tinggi badan lebih dari $Z$ score 2 menggunakan baku antropometri anak balita WHO 2005 berturut-turut 12,2\%, $14,0 \%$, dan $11,9 \%$, serta anak berusia $5-12$, 13-15, dan 16-18 tahun berturut-turut 8,8\%, $2,5 \%$, dan $1,6 \%$ berdasarkan indeks massa tubuh menurut umur lebih dari $Z$ score 2 menggunakan buku antropometri WHO 2007 untuk anak berumur 5-18 tahun. ${ }^{2}$ Di Indonesia, berdasarkan penelitian multisenter di 10 kota besar di Indonesia, didapatkan prevalensi obesitas pada anak usia sekolah dasar (SD) sekitar $12 \% .^{3}$

Menurut data Riskesdas (2010) sebesar 2,5 \% remaja berumur 13-15 tahun masuk dalam kategori gizi lebih berdasarkan IMT dan remaja umur 16-18 tahun sebanyak 1,4 $\%$ masuk dalam kategori gizi lebih berdasarkan IMT. ${ }^{4-6}$ Hanya pada beberapa kasus, kelebihan berat badan disebabkan oleh kondisi medis seperti gangguan hormonal. Jika kebiasaan-kebiasaan tersebut tidak segera ditangani maka akan berdampak buruk pada kesehatan anak. ${ }^{7,8}$
Asam urat merupakan produk akhir dari katabolisme purin dalam tubuh manusia. Hati dan mukosa pencernaan merupakan organ yang banyak memroduksi asam urat. ${ }^{9}$ Penyebab meningkatnya kadar asam urat dipengaruhi oleh berbagai macam faktor antara lain alkohol, genetik, hipotiroid, obesitas, dan diet tinggi purin. ${ }^{10}$ Peningkatan kegemukan dan obesitas pada anak di seluruh dunia ikut mendongkrak prevalensi hipertensi pada anak, terutama hipertensi primer.

Obesitas diketahui merupakan salah satu faktor yang meningkatkan resiko hipertensi primer pada anak. Selain itu juga peningkatan kadar asam urat pada anak obes berpengaruh terhadap peningkatan tekanan darah. Dalam sebuah penelitian yang dilakukan oleh Soletsky B (2013) tentang hubungan asam urat dengan peningkatan tekanan darah pada remaja umur 11-17 tahun didapatkan hasil bahwa setelah diberikan penurun asam urat maka terjadi penurunan yang signifikan pada tekanan darah. ${ }^{11}$ Prevalensi obesitas (persentil >95) pada anak rentang usia 5-15 tahun sebesar $8,3 \% .^{12}$

\section{METODE PENELITIAN}

Jenis penelitian ini ialah analitik observasional dengan desain potong lintang. Penelitian dilakukan pada bulan Oktober 2015-Januari 2016. Populasi penelitian ialah 252 siswa SMP yang ada di Kecamatan Talawaan, Kabupaten Minahasa Utara.

Kriteria inklusi meliputi siswa yang tergolong obes menurut tinggi badan dan berat badan berdasarkan umur, usia 13-15 tahun, tidak dalam keadaan sakit serta bersedia ikut dalam penelitian. Kriteria 
eksklusi meliputi siswa yang sakit atau dalam masa pengobatan serta siswa yang tidak bersedia menjadi sampel penelitian. Sampel penelitian berjumlah 38 anak obes. Variabel yang digunakan untuk variabel bebas kadar asam urat dan variabel tergantung tekanan darah (sistolik \& diastolik). Analisis data menggunakan uji statistik Pearson correlation pada program SPSS versi 22.

\section{HASIL PENELITIAN}

Hasil penelitian tentang hubungan antara kadar asam urat dengan tekanan darah sistol dan diastol disajikan dalam bentuk analisis univariat yang mencakup karakteristik umur, jenis kelamin, tekanan darah sistol dan diastol, nilai mean, standar deviasi, nilai minimum dan maksimum dari masing-masing variabel penelitian.

Analisis bivariat mencakup hasil deskriptif tabulasi silang kadar asam urat dengan tekanan darah sistol dan diastol pada responden laki-laki dan perempuan, hubungan kadar asam urat dengan tekanan darah sistol dan hubungan kadar asam urat dengan tekanan darah diastol.

\section{Analisis Univariat}

Pada Tabel 1 dapat dilihat bahwa 38 responden, sebagian besar ialah anak perempuan berjumlah 24 responden (63,2\%) sedangkan laki-laki berjumlah 14 responden $(36,8 \%)$.

Tabel 1. Distribusi Frekuensi Responden Berdasarkan Jenis Kelamin

\begin{tabular}{ccc}
\hline Jenis kelamin & $\mathrm{n}$ & $\%$ \\
\hline Laki-laki & 14 & 36,8 \\
Perempuan & 24 & 63,2 \\
Total & 38 & 100 \\
\hline
\end{tabular}

Berdasarkan Tabel 2 dapat dilihat bahwa sebagian besar responden berada pada kategori umur 13 tahun yang berjumlah 17 responden (44,7\%), umur 14 tahun berjumlah 17 responden $(44,7 \%)$ dan umur 15 tahun berjumlah 4 responden $(10,5 \%)$.
Tabel 2. Distribusi Frekuensi Responden Berdasarkan Umur

\begin{tabular}{ccc}
\hline Umur & $\mathrm{n}$ & $\%$ \\
\hline 13 Tahun & 17 & 44,7 \\
14 Tahun & 17 & 44,7 \\
15 Tahun & 4 & 10,5 \\
Total & 38 & 100 \\
\hline
\end{tabular}

Pada Tabel 3 dapat dilihat bahwa dari 14 responden laki-laki, tekanan darah sistol dengan kategori normal pada 8 responden (57\%) dan kategori tidak normal pada 6 responden (43\%).

Tabel 3. Distribusi Frekuensi Responden LakiLaki Obes Berdasarkan Tekanan Darah Sistolik

\begin{tabular}{ccc}
\hline $\begin{array}{c}\text { Tekanan Darah } \\
\text { Sistol }\end{array}$ & $\mathrm{n}$ & $\%$ \\
\hline Normal & 8 & 57 \\
Tidak Normal & 6 & 43 \\
Total & 14 & 100 \\
\hline
\end{tabular}

Pada Tabel 4 dapat dilihat bahwa dari 24 responden perempuan yang mempunyai tekanan darah sistol dengan kategori normal sejumlah 11 responden (45,8\%) dan yang kategori tidak normal sejumlah 13 responden $(54,2 \%)$.

Tabel 4. Distribusi Frekuensi Responden Perempuan Obes Berdasarkan Tekanan Darah Sistolik

\begin{tabular}{ccc}
\hline $\begin{array}{c}\text { Tekanan Darah } \\
\text { Sistol }\end{array}$ & $\mathrm{n}$ & $\%$ \\
\hline Normal & 11 & 45,8 \\
Tidak Normal & 13 & 54,2 \\
Total & 24 & 100 \\
\hline
\end{tabular}

Berdasarkan Tabel 5 dapat dilihat bahwa dari 14 responden laki-laki yang mempunyai ukuran tekanan darah diastol dengan kategori normal sejumlah 12 responden (86\%) dan yang tidak normal sejumlah 2 responden (14\%).

Berdasarkan Tabel 6 dapat dilihat bahwa dari 24 responden perempuan yang dijadikan sampel penelitian yang mempunyai ukuran tekanan darah diastol dengan kategori normal dengan jumlah 14 
responden (58\%) dan yang tidak normal berjumlah 10 responden (42\%).

Tabel 5. Distribusi Frekuensi Responden Lakilaki Obes Berdasarkan Tekanan Darah Diastolik

\begin{tabular}{ccc}
\hline $\begin{array}{c}\text { Tekanan Darah } \\
\text { Diastolik }\end{array}$ & $\mathrm{n}$ & $\%$ \\
\hline Normal & 12 & 86 \\
Tidak Normal & 2 & 14 \\
Total & 14 & 100 \\
\hline
\end{tabular}

Tabel 6. Distribusi Frekuensi Responden Perempuan Obes Berdasarkan Tekanan Darah Diastolik

\begin{tabular}{ccc}
\hline $\begin{array}{c}\text { Tekanan Darah } \\
\text { Diastolik }\end{array}$ & $\mathrm{n}$ & $\%$ \\
\hline Normal & 14 & 58 \\
Tidak Normal & 10 & 42 \\
Total & 24 & 100 \\
\hline
\end{tabular}

Berdasarkan Tabel 7 dapat dilihat bahwa rerata variabel asam urat responden $4,858 \mathrm{mg} / \mathrm{dL}(\mathrm{SD} \pm 0,9328)$, nilai minimum $2,7 \mathrm{mg} / \mathrm{dL}$, dan nilai maksimum 7,1 mg/dL. Rerata tekanan darah sistolik responden 123,16 mmHg ( $\mathrm{SD} \pm 12,967)$, dengan nilai minimum $90 \mathrm{mmHg}$, dan nilai maksimum $150 \mathrm{mmHg}$. Rerata tekanan darah diastolik responden $81,58 \mathrm{mmHg} \quad(\mathrm{SD} \pm 11,514)$ dengan nilai minimum $60 \mathrm{mmHg}$, dan nilai maksimum $100 \mathrm{mmHg}$.

Tabel 8 memperlihatkan bahwa dari 14 responden laki-laki yang mempunyai kadar asam urat kategori normal dan tekanan darah sistolik normal sebanyak 8 responden (57\%) dan responden yang mempunyai kadar asam urat kategori normal dan tekanan darah tidak normal sebanyak 6 responden (43\%).

Tabel 7. Nilai Mean, SD, Minimum dan Maksimum

\begin{tabular}{ccccc}
\hline & Mean & SD & Min & Maks \\
\hline Asam Urat & 4,858 & 0,9328 & 2,7 & 7,1 \\
TD Sistolik & 123,16 & 12,967 & 90 & 150 \\
TD Diastolik & 81,58 & 11,514 & 60 & 100 \\
\hline
\end{tabular}

Tabel 9 memperlihatkan bahwa dari 24 responden perempuan yang mempunyai kadar asam urat kategori normal dan tekanan darah sistolik normal sebanyak 10 responden (42\%), sednagkan responden yang mempunyai kadar asam urat kategori normal dan tekanan darah sistolik tidak normal sebanyak 12 responden (50\%). Responden yang mempunyai kadar asam urat kategori normal dan tekanan darah sistolik tidak normal sebanyak 2 responden (8\%).

Tabel 10 memperlihatkan bahwa dari 14 responden laki-laki, yang mempunyai kadar asam urat dengan kategori normal dan tekanan darah diastolik normal sebanyak 12 responden (86\%), sedangkan responden yang mempunyai kadar asam urat dengan kategori normal dan tekanan darah diastolik tidak normal sebanyak 2 responden (14\%).

\section{Analisis Bivariat}

\section{Hasil Deskriptif Kadar Asam Urat Berdasarkan Tekanan Darah Sistol}

Tabel 8. Hasil Tabulasi Silang Kadar Asam Urat Berdasarkan TD Sistolik Pada Responden Laki-laki Obes

\begin{tabular}{|c|c|c|c|c|c|c|c|}
\hline & & \multicolumn{4}{|c|}{ TD Sistolik } & \multirow{2}{*}{\multicolumn{2}{|c|}{ Total }} \\
\hline & & \multicolumn{2}{|c|}{ Normal } & \multicolumn{2}{|c|}{ Tidak Normal } & & \\
\hline & & $\mathrm{n}$ & $\%$ & $\mathrm{n}$ & $\%$ & $\mathrm{n}$ & $\%$ \\
\hline \multirow{2}{*}{$\begin{array}{c}\text { Kadar } \\
\text { Asam Urat }\end{array}$} & Normal & 8 & 57 & 6 & 43 & 14 & 100 \\
\hline & Tidak Normal & 0 & 0 & 0 & 0 & 0 & 0 \\
\hline \multicolumn{2}{|c|}{ Total } & 8 & 57 & 6 & 43 & 14 & 100 \\
\hline
\end{tabular}


Tabel 9. Hasil Tabulasi Silang Kadar Asam Urat Berdasarkan TD Sistolik Pada Responden Perempuan Obes

\begin{tabular}{|c|c|c|c|c|c|c|c|}
\hline & & \multicolumn{4}{|c|}{ TD Sistolik } & \multirow{2}{*}{\multicolumn{2}{|c|}{ Total }} \\
\hline & & \multicolumn{2}{|c|}{ Normal } & \multicolumn{2}{|c|}{ Tidak Normal } & & \\
\hline & & $\mathrm{n}$ & $\%$ & $\mathrm{~N}$ & $\%$ & $\mathrm{n}$ & $\%$ \\
\hline \multirow{2}{*}{$\begin{array}{c}\text { Kadar Asam } \\
\text { Urat }\end{array}$} & Normal & 10 & 42 & 12 & 50 & 22 & 100 \\
\hline & Tidak Normal & 0 & 0 & 2 & 8 & 2 & 0 \\
\hline \multicolumn{2}{|c|}{ Total } & 10 & 42 & 14 & 58 & 24 & 100 \\
\hline
\end{tabular}

\section{Hasil Deskriptif Kadar Asam Urat Berdasarkan TD Diastol}

Tabel 10. Hasil Tabulasi Silang Kadar Asam Urat Berdasarkan TD Diastolik Pada Responden Lakilaki Obes

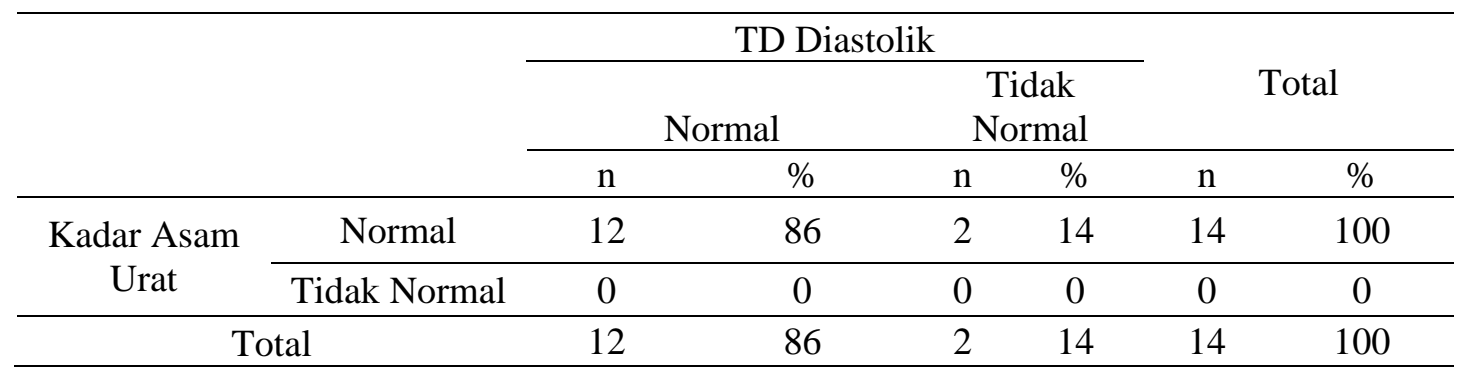

Tabel 11. Hasil Tabulasi Silang Kadar Asam Urat Berdasarkan TD Diastolik Pada Responden Perempuan Obes

\begin{tabular}{|c|c|c|c|c|c|c|c|}
\hline & \multicolumn{4}{|c|}{ TD Diastolik } & \multirow{2}{*}{\multicolumn{2}{|c|}{ Total }} \\
\hline & & \multicolumn{2}{|c|}{ Normal } & \multicolumn{2}{|c|}{ Tidak Normal } & & \\
\hline & & $\mathrm{n}$ & $\%$ & $\mathrm{n}$ & $\%$ & $\mathrm{n}$ & $\%$ \\
\hline \multirow{2}{*}{$\begin{array}{c}\text { Kadar } \\
\text { Asam Urat }\end{array}$} & Normal & 13 & 54 & 9 & 38 & 22 & 92 \\
\hline & Tidak Normal & 1 & 4 & 1 & 4 & 2 & 8 \\
\hline & Total & 13 & 54 & 9 & 42 & 24 & 100 \\
\hline
\end{tabular}

Tabel 11 menggambarkan bahwa dari 24 responden perempuan, yang mempunyai kadar asam urat dengan kategori normal dan tekanan darah diastolik normal sebanyak 13 responden (54\%), sedangkan responden yang mempunyai kadar asam urat dengan kategori normal dan tekanan darah diastolik tidak normal sebanyak 9 responden (38\%). Responden yang mempunyai kadar asam urat dengan kategori tidak normal dan tekanan darah diastolik normal sebanyak 1 responden (4\%) sedangkan responden yang mempunyai kadar asam urat dengan kategori tidak normal dan tekanan darah diastolik tidak normal sebanyak 1 responden (4\%).

Hubungan Kadar Asam Urat dengan Tekanan Darah Sistol

Tabel 12 menjelaskan bahwa hasil uji Pearson correlation mendapatkan nilai signifikan 0,306 dan nilai Pearson correlation sebesar 0,061. Karena nilai signifikan 0,306>0,02 maka terdapat hubungan positif namun secara statistik 
tidak bermakna antara kadar asam urat dengan tekanan darah sistolik.

Tabel 12. Hubungan Kadar Asam Urat dengan Tekanan Darah Sistolik

\begin{tabular}{ccc}
\hline Variabel & $\mathrm{r}$ & $\mathrm{p}$ \\
\hline $\begin{array}{c}\text { Asam Urat-Tekanan } \\
\text { Darah Sistolik }\end{array}$ & 0,306 & 0,061 \\
\hline
\end{tabular}

\section{Hubungan Kadar Asam Urat dengan Tekanan Darah Diastol}

Tabel 13 menjelaskan bahwa hasil uji Pearson correlation mendapatkan nilai signnifikan 0,152 dan nilai Pearson correlation sebesar 0,361. Karena nilai signifikan 0,152>0,02 maka terdapat hubungan positif namun secara statistik tidak bermakna antara kadar asam urat dengan tekanan darah diastolik.

Tabel 13. Hubungan Kadar Asam Urat dengan Tekanan Darah Diastolik

\begin{tabular}{ccc}
\hline Variabel & $\mathrm{r}$ & $\mathrm{P}$ \\
\hline $\begin{array}{c}\text { Asam Urat-Tekanan } \\
\text { Darah Diastolik }\end{array}$ & 0,152 & 0,361 \\
\hline
\end{tabular}

\section{BAHASAN}

Penelitian ini dilakukan pada siswa dan siswi di dua SMP negeri di Kecamatan Talawaan, Kabupaten Minahasa Utara dari kelas 1 sampai dengan kelas 3 dengan jumlah populasi sebanyak 252 anak. Sampel yang diambil menggunakan metode consecutive sampling. Dari hasil uji Pearson correlation pada hubungan antara kadar asam urat dengan tekanan darah sistolik diperoleh nilai $\mathrm{r}=0,306$ dan nilai $\mathrm{p}$ $=0,061$. Dari hasil tersebut dinyatakan bahwa terdapat hubungan positif antara kadar asam urat dengan tekanan darah sistolik namun secara statistik tidak bermakna $(\mathrm{r}=0,306, \mathrm{p}=0,062)$. Kemudian dari hasil uji Pearson correlation pada hubungan antara kadar asam urat dengan tekanan darah diastolik diperoleh nilai $\mathrm{r}=$ 0,152 dan nilai $\mathrm{p}=0,361$. Dari hasil tersebut dinyatakan bahwa terdapat hubungan positif antara kadar asam urat dengan tekanan darah diastolik namun secara statistik tidak bermakna $(r=0,152$, $\mathrm{p}=0,361)$.

Hal ini sejalan dengan penelitian yang dilakukan pada mahasiswa pria yang mengalami obesitas sentral di Fakultas Kedokteran Universitas Sam Ratulangi, yang melaporkan bahwa ada hubungan antara kadar asam urat dengan tekanan darah sistolik maupun tekanan darah diastolik. $^{13}$ Berbagai faktor dapat memengaruhi hasil penelitian tersebut seperti faktor lingkungan, budaya, status gizi, jenis kelamin, jenis makanan yang dikonsumsi sehari-hari yang berbeda disetiap tempat, aktifitas fisik dari sampel yang diteliti serta usia sampel.

Asam urat juga menstimulasi sintesis monocyte chemoattractant protein-1 (MCP-1) pada otot polos tikus melalui aktivasi p38 MAP kinase, faktor transkripsi nuklear dan AP-1. MCP-1 sendiri merupakan kemokin yang berperan penting dalam penyakit vascular dan aterosklerosis. Akibat dari mekanisme tersebut ialah peningkatan produksi sitokin proinflamasi seperti TNF- $\alpha$, IL-1 $\beta$, dan IL-6. IL-6 yang juga dikenal sebagai hepatocyte stimulating factor merangsang hepatosit untuk memroduksi HRCP yang selanjutnya menurunkan produksi NO dengan cara menghambat enzim nitrik oksida sintetase (eNOS). ${ }^{14}$

Peningkatan produksi asam urat menyebabkan pemecahan ATP menjadi adenosine dan xantin. Hal tersebut menciptakan suatu lingkaran setan. Kondisi hiperurisemia meningkatkan aktivitas enzim xantin oksidase yang selanjutnya juga membentuk superoksida sebagai akibat langsung aktivitasnya. Peningkatan jumlah oksidan menyebabkan stres oksidatif yang semakin menurunkan produksi NO dan memperparah disfungsi endotel yang terjadi. ${ }^{15}$

Dalam penelitian ini, berdasarkan jenis kelamin didapatkan bahwa sebagian besar responden penelitian perempuan (63,2\%). Hasil tersebut sesuai dengan penelitian Rau et al. yang dilakukan di Fakultas Kedokteran Universitas Sam Ratulangi untuk mengetahui perbandingan kadar asam urat pada subyek obes dan non-obes. 
Pada penelitian ini dipakai subyek berjenis kelamin pria karena adanya perbedaan status hormonal yaitu hormon estrogen. Pada wanita, hormon estrogen berperan dalam meningkatkan ekskresi asam urat melalui ginjal. Hal ini menjelaskan mengapa peningkatan kadar asam urat pada wanita umumnya terjadi pada saat menopause. ${ }^{16}$

Berdasarkan penjelasan diatas, dapat dipahami adanya hubungan positif walaupun secara statistik tidak bermakna antara kadar asam urat dengan tekanan darah sistolik maupun tekanan darah diastolik pada anak obes.

Limitasi penelitian yaitu terbatasnya jumlah sampel anak obes pada SMP di Kecamatan Talawaan serta sedikitnya jumlah sampel yang bersedia berpartisipasi dalam penelitian yang dapat memengaruhi hasil penelitian.

\section{DAFTAR PUSTAKA}

1. de Onis M, Blossner M, Borghi E. Global Prevalence and Trends of Overweight and Obesity Among Preschool Children. Am J Clin Nutr. 2010;92: 1257-64

2. Badan Penelitian dan Pengembangan Kesehatan. Kementerian Kesehatan RI Tahun 2013. Riset Kesehatan Dasar, 2013.

3. Sjarif RD. Obesitas pada Anak dan Permasalahannya. In: Hot Topics in Pediatric II. 2. Jakarta: FKUI, 2002; p.. 219-31.

4. BPPK KemenKes RI. Riskesdas 2010. Jakarta, 2010. [cited 03 Oktober 2015]. Available from:

http://www.litbang.depkes.go.id/sites/d ownload/buku_laporan/lapkas_riskesda s2010/Laporan_riskesdas_2010.pdf

5. Zulfa F. Hubungan Kebiasaan Konsumsi Fast Food Modern dengan Status Gizi (BB/TB Z-Score) di SD AL-Muttaqin Tasikmaya. FKM-UNSIL 2011. Available from:

http://journal.unsil.ac.id/jurnal/prosidin g/9/9fitri_14.pdf.pdf

6. Profil Kesehatan Indonesia 2008. Jakarta, 2009. [cited 03 Oktober 2015]. Available from:http://www.depkes.go.id/resource s/download/pusdatin/profil-KesehatanIndonesia/profil-kesehatan-indonesia2008.pdf

7. Benaroch R. Obesity in Children [internet]. 2014 [updated 2014 January 02]. Avalaible from:

http://children.webmd.com/guide/obesi ty-children

8. Centers for Disease Control and Prevention. Childhood Obesity Facts [internet]. 2015 [updated August 27, 2015]. Avalaible from:

http://www.cdc.gov/healthyyouth/obesi ty/facts.htm

9. Qazi Y. Hyperuricemia, eMedicine [internet]. 2015 [updated September 15, 2014]. Avalaible from:

http://emedicine.medscape.com/article/ 241767-overview

10. Manampiring AE, Bodhy W. Prevalensi Hiperurisemia pada Remaja Obese di Kota Tomohon. Universitas Sam Ratulangi; 2010 [citied 2015 Oct]. Avalaible from:

http://repo.unsrat.ac.id/251/1/Prevalens i_Hiperurisemia_pada_Remaja_Obese Di_KotaTomohon.pdf

11. Soletsky B, Feig ID. Uric Acid Reduction Rectifies Prehypertension in Obese Adolescents. Hypertension. 2012;60: 1148-56.

12. Sartika RAD. Faktor Resiko Obesitas pada Anak 5-15 Tahun di Indonesia Riskesdas tahun 2007. Makara Kesehatan UI. 2011:15(1);37-43.

13. Mansur SN, Wantania F, Surachmanto E. Hubungan Antara Kadar Asam Urat dengan Tekanan Darah Pada Mahasiswa Pria Obesitas Sentral Fakultas Kedokteran Universitas Sam Ratulangi. e-Clinic. 2015;3(1):381-7.

14. Bratawidjaja KG. Imunologi Dasar. Jakarta: FKUI, 2002; p. 44-53.

15. Heinig M, Johnson RJ. Role of Uric Acid in Hypertension, Renal Disease, and Metabolic Syndrome. Cleveland Clinic Journal of Medicine. 2006:1059-64.

16. Rau E, Ongkowijaya J, Kawengian V. Perbandingan Kadar Asam Urat Pada Subyek Obes dan Non-Obes di Fakultas Kedokteran Universitas Sam Ratulangi. e-Clinic. 2015;3(2):667. 